\title{
Urgensi Perubahan Kebijakan SDM RRI untuk Mendukung Transformasi Menjadi Radio Publik
}

\author{
Darmanto \\ Peneliti Balai Pengkajian dan Pengembangan Komunikasi dan Informatika Balitbang SDM \\ Kementerian Komunikasi dan Informatika
}

\begin{abstract}
It has been a decade after Radio Republik Indonesia (RRI) was set to be a public radio, but it has not shown a significant progress in the transformation process. Based on conceptual studies, it is known that there are many factors that make the transformation process of public radio become noticeably sluggish. One of the most prominent cause is the influential factor of human resources (HR). Civil servant status that carried by a majority of employees in RRI, is a major cause of HR problem. Hodling this status, they can not adapt to the demands of public radio. Therefore, it is necessary to change HR policies to be able to create people who will enhance the acceleration in transformation into public radio. In order to be effectively implemented, then it must be in the form of legislation.
\end{abstract}

Keywords: $H R$ policies, RRI, public radio, transformation

\begin{abstract}
Abstrak
Meskipun sudah satu dasawarsa Radio Republik Indonesia (RRI) ditetapkan menjadi radio publik, tetapi proses transformasinya terasa lamban. Berdasarkan kajian konseptual dapat diketahui adanya banyak faktor yang menjadikan proses transformasi menjadi radio publik terasa lamban. Salah satu penyebab yang dirasa paling menonjol pengaruhnya adalah faktor sumber daya manusia (SDM). Status Pegawai Negeri Sipil (PNS) yang disandang oleh mayoritas karyawan RRI, menjadi sebab utama dari kronisnya permasalahan SDM karena tidak mampu menyesuaikan tuntutan kinerja sebagai radio publik. Oleh karena itu diperlukan adanya perubahan kebijakan SDM untuk dapat melahirkan orang-orang yang mampu mendorong terjadinya percepatan transpormasi menjadi radio publik. Agar kebijakan publik yang dimaksud bisa lebih efektif, maka wujudnya harus undang-undang.
\end{abstract}

Kata Kunci: Kebijakan SDM, RRI, radio publik, transformasi

\section{Pendahuluan}

Terhitung sejak disahkannya Undangundang Penyiaran tahun 2002, usia Lembaga Penyiaran Publik (LPP) di Indonesia telah genap satu dasawarsa. Namun, implementasi pelaksanaan LPP sendiri secara nyata baru dimulai setelah lahirnya Peraturan Pemerintah (PP) No.
11, 12, dan 13 tahun 2005, dan itu pun yang kelihatan dinamikanya cukup tinggi hanya LPP Nasional, yaitu RRI dan TVRI. Sedangkan untuk lembaga penyiaran publik lokal wacananya masih sangat lemah, apalagi pelaksanaannya.

Akan tetapi, artikel ini tidak dimaksudkan untuk mendiskusikan 
keberadaan lembaga penyiaran publik secara keseluruhan seperti dimaksud pada Bagian Keempat Pasal 14-15 UU No. 32/2002 dan aturan pelaksanaannya di tiga PP tersebut di aras. Pembahasan ini hanya akan diarahkan pada isu lambannya proses transformasi Radio Republik Indonesia dari status sebelumnya sebagai lembaga penyiaran pemerintah menjadi Lembaga Penyiaran (radio) Publik, terutama dikaitkan dengan persoalan Sumber Daya Manusia (SDM).

Sebenarnya ada banyak faktor yang menyebabkan proses transformasi RRI dari kedudukannya sebagai radio pemerintah (Orde Baru) menjadi radio publik, berjalan lamban. Faktor-faktor tersebut secara garis besar dapat dikelompokkan menjadi dua, yaitu faktor struktural dan kultural. Merujuk pada Wahyono, dkk (2011: 3-5), yang dimaksud dengan faktor struktural adalah kekuatan yang datang dari luar dalam bentuk peraturan perundangan yang berlaku. Sedangkan faktor kultural bersifat laten dan muncul dari lingkungan sosial yang kemudian termanifestasikan dalam bentuk sikap mental dan perilaku manusia.

Secara struktural, peraturan perundangan yang menjadi landasan hukum bagi operasionalisasi LPP RRI sekarang ini belum mampu mendorong terjadinya perubahan secara radikal. Aspek sumber pembiayaan, model pengelolaan lembaga, struktur organisasi, sistem manajemen Sumber Daya Manusia
(SDM) atau pegawai, dan aspek lainnya, hampir tidak ada bedanya dengan ketika RRI masih menjadi Unit Pelaksana Teknis (UPT) Departemen Penerangan di era Orde Baru. Dengan demikian wajar kalau kinerjanya tidak berbeda jauh dengan lembaga lain di jajaran pemerintahan. Sedangkan secara kultural, belum tampak adanya perubahan mendasar karena baik lingkungan sosial RRI maupun orangorang yang ada di dalamnya sebagian besar masih sama dengan era sebelumnya.

Dari dua kategori besar permasalahan yang dihadapi RRI saat ini, jika ditelisik secara seksama maka yang terasa paling krusial adalah di aspek SDM. Permasalahan mendasar yang ada saat ini adalah dari segi kuantitas jumlahnyamelebihi kebutuhan, tetapi kualitasnya sangat rendah. Di sisi lain, pihak manajemen tidak dapat berbuat banyak untuk melakukan penataan ulang secara radikal karena ada hambatan struktural.

Sebagian besar SDM RRI sekarang ini adalah warisan Orde Baru yang berstatus sebagai Pegawai Negeri Sipil (PNS). Dalam aturan kepegawaian PNS, manajemen tidak mudah memecat pegawai yang sebenarnya sudah tidak dibutuhkan lembaga karena kinerjanya rendah dan justru hanya menambah beban. Oleh karena itu, pihak manajemen harus tetap mempekerjakan SDM yang sebenarnya sudah tidak mampu menyesuaikan dinamika zaman, dan hasilnya akan tetap mengecewakan. 
Dalam hal pembinaan karier pegawai, pihak manajemen juga harus mengikuti aturan perundangan yang berlaku bagi PNS. Karenanya sering terjadi, ada pegawai yang dipromosikan karena menurut peraturan perundangan kepegawaian memang memenuhi syarat, tetapi dari aspek profesionalisme sebagai broadcaster sangat rendah. Ketika hal itu sering terjadi maka dengan sendirinya berpotensi merusak iklim kerja di lingkungan RRI. Pegawai yang syarat formalnya belum memenuhi untuk diangkat menjadi pejabat struktural, tetapi secara profesionalisme diakui oleh teman-teman mereka, biasanya kemudian membentuk kelompok yang memosisikan diri sebagai pihak yang merasa dimarginalisasikan dan pada akhirnya menibulkan suasana disharmoni.

Bertitik tolak dari latar belakang tersebut, artikel konseptual ini akan memfokuskan pembahasan pada isu urgensi perubahan kebijakan SDM RRI untuk mendorong percepatan transformasi menjadi radio publik. Kajian ini bertujuan untuk mengidentifikasi permasalahan struktural di bidang SDM yang berpotensi menghambat proses transpormasi RRI dari lembaga penyiaran pemerintah menjadi radio publik dan berusaha menemutunjukkan alternatif pemecahan yang perlu diambil. Kajian ini didasarkan pada sumber-sumber kepustakaan yang relevan, pengalaman empirik selama 20 tahun bekerja di RRI, maupun data dan informasi yang diperoleh melalui keterlibatan penulis dalam sejumlah riset tentang RRI, sebagai narasumber dan fasilitator dalam sejumlah kegiatan di RRI.

\section{Kerangka Konseptual}

Sebelum mendiskusikan lebih lanjut, kiranya perlu adanya pembatasan konseptual tentang apa yang dimaksudkan dengan urgensi perubahan kebijakan SDM RRI. Batasan konseptual dimaksudkan untuk menghindari timbulnya perbedaan persepsi antara penulis dengan pembaca artikel. Sehubungan dengan hal tersebut, maka pada bagian ini hendak dijelaskan apa yang sebenarnya dimaksudkan oleh penulis tentang perubahan kebijakan SDM RRI.

Dalam kehidupan sehari-hari masyarakat sudah familier menggunakan istilah kebijakan (policy term) seperti "kebijakan pertanian, kebijakan pendidian, kebijakan kependudukan, kebijakan Pemda, kebijakan sekolah" dan lainnya. Istilah kebijakan sering dipertukarkan dengan tujuan (goals), program, keputusan (decisions), standard, proposal, dan grand design. Penggunaan istilah kebijakan mempunyai banyak dimensi seperti analisis kebijakan, perumusan kebijakan, menunjuk pada pengertian.

Secara khusus, penggunaan istilah "kebijakan" menunjuk pada perilaku aktor (bisa pejabat atau lembaga) dalam bidang tertentu untuk konteks yang pragmatik. 
Sedangkan untuk kepentingan yang sifatnya ilmiah, penggunaan istilah "kebijakan" saja, dirasa kurang memadai sehingga muncul istilah "kebijakan publik" (Winarno, 2008: 15-16). Dalam artikel ini, istilah kebijakan (policy term) digunakan secara bergantian untuk merujuk pada makna pragmatik maupun konsep kebijakan publik.

Adapun definisi tentang kebijakan publik itu sendiri banyak ragamnya. Namun, berangkat dari pendapat sejumlah ahli seperti Thomas R. Dye, Richard Rose, Carl Friedrich, James Anderson, dan Amir Santoso; Winarno mendefinisikan kebijakan publik sebagai serangkaian instruksi dari para pembuat keputusan kepada pelaksana kebijakan yang menjelaskan tujuan-tujuan dan caracara untuk mencapai tujuan tersebut (Winarno, 2008: 19).

Dwidjowijoto, yang juga mendasarkan pendapatnya dari berbagai ahli mendefinisikan kebijakan publik adalah kebijakan yang dibuat oleh administratur negara atau administratur publik atau segala sesuatu yang dikerjakan dan yang tidak dikerjakan oleh pemerintah. Dengan demikian pihak yang membuat kebijakan publik adalah pemerintah negara dengan maksud untuk mengatur kehidupan bersama atau kehidupan publik, dan mempunyai efek eksternalitas (Dwidjowijoto, 2006: 2327).
Kebijakan publik lahir dari tarikmenarik kepentingan yang melibatkan sedikit tiga dimensi sekaligus, yaitu dimensi politik, hukum, dan dimensi manajemen. Secara politis, kebijakan publik merupakan representasi dari sistem politik yang berlaku. Dalam sistem politik yang demokratis, kebijakan publik lahir lewat proses demokratis dan ditujukan untuk kepentingan bersama. Dari aspek hukum sangat jelas bahwa kebijakan publik merupakan fakta hukum yang bersifat mengikat terutama bagi seluruh penyelenggara pemerintahan. Sedangkan dari aspek manajemen, kebijakan publik perlu direncanakan dan dilaksanakan oleh pemerintah beserta organisasi eksekutif yang dipimpinnya, yaitu birokrasi (Nugroho, 2012: 93).

Mengacu pada berbagai pendapat tersebut, maka penggunaan istilah kebijakan dalam studi ini lebih merujuk kepada makna kebijakan publik. Dengan demikian yang dimaksud kebijakan SDM RRI adalah keputusan politik dari para penyelenggara negara maupun pemerintahan untuk melahirkan produk hukum berkenaan dengan keberadaan SDM RRI. Tujuannya adalah untuk mendorong percepatan transformasi RRI menjadi radio publik. Adapun jenis produk hukum yang dibuat tergantung pada kedudukan si pembuat. Produk hukum yang dibuat oleh para penyelenggara negara pada umumnya berupa Undang-undang, sedangkan yang dibuat oleh penyelenggara pemerintahan 
berupa Peraturan Pemerintah dan turunannya.

Substansi kebijakan SDM seperti apa yang dapat mendorong percepatan transformasi menjadi radio publik? Mengacu pada kompetensi inti BBC sebagai lembaga penyiaran publik yang sudah terpercaya (Shankleman, 2000: 112-120 dan 166-168), kualifikasi SDM yang dibutuhkan oleh RRI agar dapat mempercepat transformasi menjadi radio publik, yaitu:

1. Mempunyai komitmen mendalam terhadap tujuan lembaga penyiaran publik;

2. Mempunyai sikap anti komersialisme;

3. Memiliki etos pelayanan publik;

4. Mempunyai integritas moral yang tinggi;

5. Memiliki komitmen yang dalam terhadap tugas dan ketrampilan membuat program acara siaran radio;

6. Memiliki profesionalisme yang tinggi di bidang siaran radio;

7. Memiliki kemampuan memproduksi program-program yang bagus dan orisinal untuk jenis subyek yang variatif, serta menarik perhatian segala macam kelompok selera dan kepentingan;

8. Memiliki kemampuan untuk bekerja secara silang antara stasiun induk dengan jaringan;
9. Memiliki kemampuan untuk bekerja dalam tim guna menghasilkan produk yang berkualitas;

10. Memiliki kemampuan intelektual yang baik;

11. Memiliki semangat pengabdian untuk membuat yang terbaik bagi RRI sebagai radio publik;

12. Memiliki sense artistik yang tinggi di bidang siaran radio; dan

13. Memiliki daya kreativitas tinggi.

Peraturan dan perundangan yang menjadi dasar hukum manajemen SDM RRI sekarang ini sangat tidak mungkin dapat melahirkan SDM yang memenuhi kriteria tersebut di atas. Dengan demikian, arah perubahan kebijakan SDM RRI diharapkan dapat mendorong lahirnya pegawai yang memenuhi kualifikasi sebagai broadcaster lembaga penyiaran publik.

\section{Belenggu Peraturan Perundangan}

Kondisi riil SDM RRI saat ini masih jauh dari kualifikasi ideal seperti dipaparkan di atas. Mengapa? Sebab, sebagian besar dari 6.00o pegawai RRI di seluruh Indonesia saat ini berstatus sebagai PNS hasil rekrutmen pada era Orde Baru dengan dasar hukum UU No. 8 Tahun 1974. Oleh karena itu rata-rata usia mereka di atas 40 tahun dan sebagian besar berada di rentang usia antara 45-55 tahun sehingga sudah mendekasi masa 
pensiun. Sedangkan sebagian lainnya merupakan pegawai kontrak yang di lingkungan RRI lebih populer dengan sebutan PBPNS (Pegawai Bukan PNS). PBPNS merupakan rekrutmen di era reformasi, terutama setelah RRI resmi menjadi Lembaga Penyiaran Publik pada tahun 2005, dan pengangkatannya didasarkan pada Surat Keputusan Direktur Utama LPP RRI.

Dengan demikian terdapat dua dasar hukum yang berbeda dalam manajemen kepegawaian di RRI. Pertama, manajemen kepegawaian bagi yang berstatus PNS dilakukan berdasarkan UU No. 8 Tahun 1974 tentang Pokok-pokok Kepegawaian yang kemudian diubah dengan UU No. 43 Tahun 1999 tentang Perubahan atas UU No. 8 Tahun 1974 tentang Pokok-Pokok Kepegawaian, serta peraturan pelaksanaannya. Kedua, manajemen SDM bagi PBPNS dilaksanakan berdasarkan kebijakan direksi LPP RRI dengan dasar hukum Pasal 41 ayat (1 dan 3) Peraturan Pemerintah Nomor 12 Tahun 2005 tentang Lembaga Penyiaran Publik Radio Republik Indonesia (LPP RRI).

Berdasarkan hasil studi sebelumnya, diketahui bahwa perbedaan status kepegawaian di lingkungan RRI telah menimbulkan masalah tersendiri. PBPNS sebagai tenaga kontrak tidak memiliki jaminan untuk bekerja di RRI selamanya. Besaran gaji yang mereka terima juga tidak sebesar yang diterima PNS karena standar gaji mereka adalah
Upah Minimum Provinsi (UMP). Kondisi tersebut mengakibatkan timbulnya masalah baru dan cenderung merusak suasana kerja karena ada kecemburuan di antara mereka. Kalangan PNS karena merasa senior lebih banyak mendelegasikan pekerjaan kepada PBPNS. Akan tetapi, pihak PBPNS sesungguhnya berat hati melaksanakan tugas-tugas yang ada. Mereka merasa hanya "dimanfaatkan" oleh seniornya padahal fasilitas negara yang diberikan ke pihak PNS jauh lebih banyak dibandingkan yang mereka terima (Darmanto, dkk, 2011).

Terdapat persoalan krusial dengan adanya dualisme status kepegawaian di RRI. Namun mengingat sejumlah keterbatasan, maka kajian ini akan lebih diarahkan pada permalahan SDM RRI yang berstatus PNS. Alasannya, dibandingkan yang PBPNS, jumlah PNS di RRI jauh lebih banyak sehingga pengaruhnya lebih besar. Di samping itu karena dasar hukum manajemen kepegawaian untuk PNS adalah undangundang, maka implikasinya juga jauh lebih kompleks. Untuk mengubah salah satu ketentuan yang ada dalam UU dibutuhkan proses politik yang panjang dan anggaran yang besar. Sedangkan untuk perubahan kebijakan SDM bagi mereka yang berstatus PBPNS cukup diselesaikan di internal RRI.

Berdasarkan hasil kajian, sebagian isi dari UU No.43/1999 sebenarnya sudah sesuai dengan semangat demokrasi. 
Dalam UU ini terdapat larangan bagi Pegawai Negeri agar tidak menjadi anggota/dan atau pengurus partai politik, dan harus netral dari semua pengaruh kepentingan golongan maupun partai politik, serta tidak diskriminatif dalam memberikan pelayanan kepada masyarakat (Pasal 3). Prinsip ini sesungguhnya sangat sesuai dengan semangat RRI sebagai radio publik.

Akan tetapi, pada bagian kewajiban (Pasal 4), semangatnya masih sama dengan UU No. 8/1974, yaitu bahwa setiap Pegawai Negeri wajib setia dan taat kepada Pancasila, UUD 1945, Negara, dan Pemerintah. Klausul ini dengan sendirinya membuat PNS di lingkungan RRI sulit untuk bersikap netral dan kritikal kepada pemerintah karena mereka merasa menjadi bagian dari pemerintah itu sendiri. Apalagi jika dikaitkan dengan manajemen PNS seperti diatur dalam Bab III UU No.43/1999 bahwa kebijaksanaan manajemen PNS yang mencakup penetapan norma, standar, prosedur, formasi, pengangkatan, pengembangan kualitas sumber daya PNS, pemindahan, gaji, tunjangan, kesejahteraan, pemberhentian, hak, kewajiban, dan kedudukan hukum; semua itu berada di tangan Presiden selaku Kepala Pemerintahan. Hal ini semakin memperjelas bahwa posisi PNS sepenuhnya berada di bawah kendali eksekutif sehingga mempersulit proses penguatan RRI sebagai radio publik yang harus netral, mandiri, dan independen dari semua kekuatan politik yang ada.

Ketika mindset pegawai RRI masih tebelenggu oleh kesadaran sebagai PNS yang tidak berani kritikal kepada atasan dan merasa menjadi bagian dari pemerintah, tentu sulit diharapkan adanya percepatan transformasi RRI menjadi radio publik.

\section{Implikasi Status Kepegawaian}

Status kepegawaian karyawan RRI yang didominasi oleh PNS merupakan warisan Orde Baru yang ditumbangkan oleh gerakan Reformasi pada Mei 1998. Pada masa Orde Baru posisi RRI merupakan UPT dari Deppen. Oleh Pemerintahan Presiden Abdurahman Wahid (Gus Dur), Deppen dibubarkan dengan alasan bahwa masalah informasi menjadi urusan masyarakat sendiri. Akan tetapi, RRI sebagai lembaga penyiaran tetap dianggap vital dan karenanya tidak ikut dibubarkan seperti institusi induknya, Deppen. RRI tetap berusaha eksis melalui berbagai upaya. Setelah menolak menjadi bagian dari Departemen Perhubungan, RRI kemudian memilih menjadi Perusahaan Jawatan (Perjan) sambil terus mengupayakan adanya payung hukum yang lebih kuat untuk menjadi radio publik. Pada akhirnya lahir UU No. 32/2002 tentang Penyiaran dan PP No. 12/2005 sebagai aturan pelaksanaan bagi keberadaan LPP RRI (Darmanto, 2012: 44-46). . 
Meskipun secara yuridis status RRI yang semula merupakan UPT Deppen, kemudian menjadi Perjan, dan akhirnya sebagai Lembaga Penyiaran Publik (LPP), tetapi orang-orang yang ada di dalamnnya tetap sama. Jadi, ibarat sebuah keluarga mereka masih menempati rumah dan pekarangan yang sama, anggota keluarga masih sama, dan kartu identitas yang dimiliki juga sama, tetapi "terpaksa" harus mengubah "papan namanya" untuk meyakinkan kepada publik bahwa lembaga itu benar-benar sudah berubah mengikuti amanat perundang-undangan yang berlaku. Padahal sesungguhnya hampir semua belum berubah, kecuali pada struktur organisasi yang kemudian mengenal adanya Dewan Pengawas dan Dewan Direksi.

Karena yang ada di dalam ruang dengan "papan nama baru" adalah orangorang yang sama, dengan sendirinya kultur yang berkembang juga masih sama. Sebab untuk bisa terjadinya perubahan budaya organiasi seperti dikatakan Schein, dan Kotler at al. dalam Tika (2008: 97), unsur terpenting yang diperlukan adalah kepemimpinan yang kuat. Perubahan budaya organisasi hanya mungkin terjadi jika ada pemimpin baru yang dapat mengambil langkah-langkah untuk melembagakan budaya baru dengan menciptakan pola-pola baru, berupa simbol-simbol, keyakinan, dan struktur.

Faktor kepemimpinan baru dan kuat itu tidak ditemukan di RRI selama masa transisi. Ketika Deppen dibubarkan akhir tahun 1999, pemimpin yang mengendalikan RRI tetap sama meskipun jabatannya menggunakan nomenklatur yang berlaku di lingkungan Perjan. Masa itu berlangsung sampai dengan pertengahan tahun 2005 dengan dilantiknya direksi yang baru sesuai PP No. 12/2005.

Kehadiran Parni Hardi sebagai Direktur Utama di era LPP periode I sebenarnya memberikan harapan baru karena mempunyai visi jelas dan wibawa, tetapi karena belum sempat terinternalisasikan dengan baik dan yang bersangkutan tidak menjabat lagi, maka hasilnya belum sempat mengakar. Celakanya, yang terjadi kemudaian adalah upaya "deparnihardisasi" sehingga potret kepemimpinan yang kuat semakin hilang. Pegawai RRI semakin kehilangan sosok kepemimpinan yang kuat dan mampu membawa gerbang RRI menjadi radio publik yang ideal.

Dengan demikian, pada masa-masa kritis, masa transisi dari UPT menuju radio publik tidak ada pemimpin baru yang hadir di RRI. Sebaliknya, yang terjadi adalah konsolidasi untuk penguatan kultur yang sudah lama terbentuk. Bahkan pilihan kelembagaan di masa transisi adalah Perjan dikandung maksud agar tidak ada risiko terhadap status kepegawaian mengingat pilihan karyawan RRI tetap ingin menjadi PNS. Seperti diketahui bahwa Perjan memang membolehkan pegawainya berstatus sebagai PNS, sehingga dengan sendirinya 
pilihan status itu sejak awal sudah menimbulkan dilema tersendiri bagi RRI untuk menjadi radio publik (Darmanto, 2004: 244-246).

Pilihan status untuk tetap sebagai PNS mengindikasikan adanya keengganan untuk berubah. Padahal seperti kita ketahui, birokrasi pemerintahan di Indonesia sejak awal memang sudah bermasalah karena sarat dengan politisasi. Oleh karenanya pembangunan etos kerja pun mengalami feodalisasi di mana bawahan dalam penyelesaian pekerjaan hanya berorientasi pada petunjuk pimpinan, dan minim inisiatif karena takut salah sehingga yang tampak adalah marginalisme di kalangan aparat birokrasi bawah (Dwiyanto, dkk, 2006: 29).

Begitu juga karakter birokrasi masa Orde Baru, cenderung memperlihatkan kuatnya penetrasi birokrasi sebagai representasi kehadiran negara ke dalam kehidupan masyarakat dan menciptakan strategi politik korporatisme negara (Dwiyanto, 2006:35-36). Padahal, seluruh pegawai RRI yang ikut menyongsong era reformasi, yaitu masa transisi menuju radio publik adalah hasil rekrutmen di era Orde Baru yang berwatak otoritarian, hegemonik, dan tidak mempunyai komitmen melayani kepentingan publik. Dengan sendirinya, karena mereka dibentuk dalam budaya organisasi yang otoritarian, hegemonik, dan rendah komitmen dalam pelayanan publik, maka rasanya mustahil mereka dapat berubah secara tiba-tiba dan langsung mampu menyesuaikan diri dengan tuntutan era baru RRI sebagai radio publik.

Seandainya hendak dikatakan telah ada perubahan budaya organisasi, maka menurut Paul Bate dalam Sobirin (2007: 338-342) tingkatannya masih tahap deformasi, yaitu perubahan budaya yang sesungguhnya belum terjadi, tetapi masih sebatas gagasan dan kesadaran bahwa perubahan budaya sangat diperlukan. Jadi masih ada tingkatan lagi, yaitu rekonsiliasi, akulturasi, dan enactive.

Pada level deformasi ini sebenarnya membutuhkan legitimasi berupa dukungan dari berbagai pihak baik internal maupun eksternal. Sayangnya, pada level pimpinan puncak RRI (Dewan Pengawas dan Dewan Direksi) yang seharusnya menjadi motor penggerak mobilisasi dukungan untuk kepentingan legitimasi, justru tidak berbuat banyak. Mereka masih memperlihatkan kultur birokrasi gaya lama dengan melakukan feodalisasi melalui ritual kunjungan ke stasiun daerah tanpa jelas hasilnya. Feodalisasi birokrasi di lingkungan RRI juga diperlihatkan dalam proses pengangkatan pejabat struktural yang sarat dengan kontestasi dukungan antarpersonal dewan pengawas maupun dewan direksi terhadap calon mereka masing-masing untuk kepentingan pencitraan diri.

Akibat belum berubahnya budaya organisasi, maka yang terjadi kemudian 
adalah konflik kultural yang tidak berkesudahan di internal RRI. Mayoritas pegawai RRI ingin tetap berada pada zona nyaman sebagai PNS karena tidak perlu bersusah payah setiap tahun mengalami kenaikan gaji, setiap dua tahun sekali menerima kenaikan gaji berkala, setiap empat tahun mengalami kenaikan pangkat, dan kecil kemungkinan mengalami Pemutusan Hubungan Kerja (PHK) selama tidak melakukan pelanggaran hukum kategori berat. Budaya birokrasi yang demikian berlawanan dengan apa yang dibutuhkan untuk dapat mewujudkan radio publik yang ideal.

\section{Kebutuhan Perubahan}

Melihat kondisi SDM RRI yang ada sekarang ini, tentu kita tidak dapat berharap banyak untuk terjadinya percepatan transformasi menjadi radio publik. Selama pegawai RRI masih didominasi oleh PNS dengan sendirinya kultur yang mereka ciptakan adalah feodalisasi birokrasi, minim inisiatif, miskin kreativitas, rendah komitmen dalam pelayanan publik, dan etos pengabdian untuk memberikan yang terbaik pada RRI cenderung rendah.

Faktanya, sebagai radio publik RRI membutuhkan tenaga yang memenuhi kualifikasi seperti tersebut sebelumnya.

Kualifikasi pegawai seperti itu tidak akan terpenuhi jika hanya mengandalkan pegawai yang ada saat ini, terutama dari kalangan PNS. Akan tetapi, selama regulasi yang menjadi dasar rekrutmen dan manajemen pegawai RRI masih UU No. 8/1974 dan UU No.43/1999 beserta peraturan pelaksanaannya, hal itu jelas tidak akan pernah mampu menyelesaikan permasalahan secara mendasar.

Sehubungan dengan itu maka diperlukan adanya perubahan kebijakan publik terkait dengan manajemen SDM RRI agar mampu mendorong terjadinya percepatan transformasi RRI dari lembaga penyiaran pemerintah menjadi lembaga penyiaran publik. Berhubung produk hukum yang dipakai dasar dalam manajemen SDM RRI sekarang berupa undang-undang, dengan sendirinya produk hukum yang akan dibuat sebagai pengganti harus satu level, yakni undangundang.

Dalam sejarahnya, kebijakan publik, apalagi yang menyangkut permasalahan strategis seperti RRI dan produk hukumnya berupa undangundang, tidak pernah lahir begitu saja. Oleh karena itu dibutuhkan perjuangan yang keras untuk mendesakkan kepada para pembuat kebijakan publik bahwa permasalahan tersebut sangat mendesak untuk dibuatkan regulasi. Mengingat isu ini tidak menarik dan bahkan cenderung mengganggu kenyamanan pegawai RRI yang berstatus PNS, dan pemerintah juga punya agenda sendiri, maka mau tidak mau kalangan masyarakat sipil (civil society) yang harus aktif memperjuangkan, melakukan advokasi, 
dan mendesakkannya di tengah agenda para pembuat kebijakan.

\section{Penutup}

Berdasarkan paparan pemikiran tersebut di muka, dapat disimpulkan bahwa proses transpormasi RRI dari radio pemerintah menuju radio publik seperti diamanatkan oleh UU Penyiaran tahun 2002, berjalan lamban dan masih jauh dari harapan. Ada banyak persoalan yang melingkupinya, tetapi salah satu faktor penting yang cukup dominan adalah kondisi SDM yang secara kuantitas melebihi kebutuhan, tetapi dari aspek kualitas cenderung rendah. Faktor penyebab rendahnya kinerja pegawai adalah karena status mereka sebagai PNS sehingga kultur yang dimiliki tidak sesuai dengan kebutuhan aktual RRI sebagai radio publik yang harus bersikap netral, mandiri, dan independen, tetapi kritikal terhadap semua kekuatan politik termasuk pemerintah.

Sehubungan dengan itu maka solusi yang ditawarkan adalah perlunya perubahan kebijakan publik terkait dengan keberadaan SDM RRI. Tentu saja, produk kebijakan yang diperlukan adalah dalam bentuk Undang-undang agar satu level dengan dasar hukum yang dipakai sekarang. Mengingat perubahan kebijakan tersebut akan sangat mengganggu kenyamanan mayoritas pegawai RRI, dan agenda pemerintah untuk menarik kembali RRI di bawah naungannya, maka upaya perubahan kebijakan SDM RRI tersebut harus diperjuangkan oleh masyarakat sipil dan pendukung demokratisasi media pada umumnya.

\section{Daftar Pustaka}

Darmanto, A. 2004. "Dilema Status Perjan RRI Menuju Terwujudnya Radio Publik", Jurnal Ilmu Komunikasi Vol. 2, Nomor 2, September-Desember.

Yogyakarta: Jurusan Ilmu Komunikasi FISIP UPN "Veteran" Yogyakarta.

Darmanto, Puji Rianto, Anang Hermawan, dan Wisnu Martha Adiputra. 2011. Laporan Pemetaan Pro 1 dan Pro 2 Radio Republik Indonesia Tahun 2011. Jakarta: Direktorat Program Dan ProduksiLPP RRI (tidak dipublikasikan).

Darmanto. 2012. "Inisiator bukan Pemimpin" dalam M. Faried Cahyono (ed.), Radio Melintas Zaman. Jakarta dan Yogyakarta: Dit PP LPP RRI dan AJI Yogyakarta.

Dwidjowijoto, Riant Nugroho. 2006. Kebijakan Publik untuk Negara-negara Berkembang. Jakarta: Elex Media Komputindo. 
Dwiyanto, Agus, dkk. 2006. Reformasi Birokrasi Publik di Indonesia. Yogyakarta: Gadjah Mada University Press.

Nugroho, Riant. 2012. Public Policy. Jakarta: Elex Media Komputindo.

Peraturan Pemerintah Nomor 12 Tahun 2005 tentang Lembaga Penyiaran Publik Radio Republik Indonesia.

Shankleman, Lucy Kung. 2000. Inside $B B C$ and CNN Perbandingan Budaya Organisasi Media (terj.: Kresno Saroso). Jakarta: Kantor Berita 68 H.

Sobirin, Ahmad. 2007. Budaya Organisasi: Pengertian, Makna dan Aplikasinya dalam Kehidupan Organisasi. Yogyakarta: UPP STIM YKPN.
Tika, Moh. Pabundu. 2008. Budaya Organisasi dan Peningkatan Kinerja Perusahaan. Jakarta: PT Bumi Aksara

Undang-Undang Nomor 32 Tahun 2002 tentang Penyiaran.

Undang-Undang Nomor 8 Tahun 1974 tentang Pokok-pokok Kepegawaian.

Undang-undang Nomor 43 Tahun 1999 tentang Perubahan atas UU No. 8 Tahun 1974 tentang PokokPokok Kepegawaian.

Wahyono, S. Bayu, dkk. 2011. Ironi Eksistensi Regulator Media di Era Demokrasi. Yogyakarta: PR2Media dan Yayasan Tifa.

Winarno, Budi. 2008. Kebijakan Publik Teori dan Proses. Yogyakarta: MedPress. 